\title{
LANDASAN PENGEMBANGAN KURIKULUM BAHASA ARAB
}

\author{
Walfajri \\ Institut Agama Islam Negeri (IAIN) Metro Lampung \\ E-mail:walfajri2018@gmail.com
}

\begin{abstract}
The curriculum and learning are two things that can not be separated. The curriculum serves as a guide that provides the direction and purpose of education and content to be learned, while learning is a process that occurs in the interaction of teaching and learning between teachers and students. Without a clear curriculum as a reference, then learning process will not take place effectively. Similarly, the curriculum will not be meaningful if it is not implemented in the learning process. The development of an Arabic learning curriculum is a never-ending process that must be done continuously. If not, then the curriculum becomes obsolete or out of date. Nevertheless, the curriculum development can not be done perfunctorily or in any old way. To produce a qualified Arabic leaning curriculum must stand on a firm foundation, among others: religious, philosophical, juridical, linguistic, psychololinguistic, sociolinguistic, and scientific and technological foundations.
\end{abstract}

Keywords: Curriculum, Arabic Teaching, Behaviorisme-Structuralisme, Cognitivisme, Comunicative Competence.

\begin{abstract}
Abstrak
Kurikulum dan pembelajaran merupakan dua hal yang tak dapat dipishakan. Kurikulum berfungsi sebagai pedoman yang memberikan arah dan tujuan pendidikan serta isi yang harus dipelajari, sedangkan pembelajaran adalah proses yang terjadi dalam interaksi belajar dan mengajar antara guru dan siswa. Tanpa kurikulum yang jelas sebagai acuan, maka pembelajaran tidak akan berlangsung secara
\end{abstract}


efektif. Demikian pula, kurikulum tidak akan bermakna jika tidak diimplementasikan dalam proses pembelajaran. Pengembangan kurikulum bahasa Arab adalah proses yang tak pernah berhenti yang harus dilakukan secara kontinu. Jika tidak, maka kurikulum tersebut menjadi usang atau ketinggalan zaman. Namun demikian, pengembangan kurikulum tidak bisa dilakukan dengan asal jadi atau secara sembarangan. Untuk menghasilkan kurikulum bahasa Arab yang berkualitas harus berpijak pada landasan yang kukuh, antara lain: landasan religius, filosofis, yuridis, linguistik, psikololinguistik, sosiolinguitik, dan landasan ilmu pengetahuan dan teknologi.

Kata Kunci: Kurikulum, Pembelajaran Bahasa Arab, StrukturalismeBehaviorisme, Kognitivisme, Kompetensi Komunikatif.

\section{A. Pendahuluan}

Kurikulum merupakan salah satu komponen yang memiliki peran penting dalam sistem pendidikan. Dalam kurikulum, dirumuskan tentang tujuan yang harus dicapai sehingga jalannya program pendidikan menjadi jelas dan terarah. Selain itu, kurikulum memberikan pemahaman belajar yang harus dimiliki oleh setiap siswa.

Selanjutnya, kurikulum dan pembelajaran merupakan dua hal yang tidak dapat dipisahkan. Kurikulum berfungsi sebagai pedoman yang memberikan arah dan tujuan pendidikan serta isi yang harus dipelajari, sedangkan pembelajaran adalah proses yang terjadi dalam interaksi belajar dan mengajar antara guru dan siswa. Tanpa kurikulum yang jelas sebagai acuan, maka pembelajaran tidak akan berlangsung secara efektif. Demikian pula, kurikulum tidak akan bermakna jika tidak diimplementasikan dalam proses pembelajaran.

Mengingat pentingnya fungsi dan peran kurikulum dalam pendidikan, maka pengembangan kurikulum tidak dapat dilakukan secara sembarangan. Pengembangan kurikulum membutuhkan landasan-landasan yang kuat, yang didasarkan pada hasil-hasil pemikiran dan penelitian yang mendalam. Pengembangan kurikulum yang tidak didasarkan pada landasan yang kuat dapat berakibat fatal terhadap kegagalan pendidikan itu sendiri.

Dengan demikian, pengembangan kurikulum bukan sesuatu yang mudah dan sederhana. Hal ini diakui oleh Nasution ${ }^{1}$, pasalnya, ada banyak hal yang harus dipertimbangkan dan banyak pertanyaan yang

\footnotetext{
${ }^{1}$ S. Nasution, Asas-Asas Kurikulum, (Jakarta: Bumi Aksara, 2006), hlm. 10.
} 
dapat diajukan untuk diperhitungkan. Misalnya: Apakah yang ingin dicapai? Manusia bagaimanakah yang diharapkan akan dibentuk? Apakah kebutuhan anak/peserta didik itu? Apakah akan diutamakan kebutuhan anak/peserta didik pada saat sekarang ataukah masa mendatang? Apakah harus dipertimbangkan anak/peserta didik sebagai individu ataukah sebagai anggota kelompok? Apakah yang harus dipentingkan, mengajarkan kejuruan ataukah memberi pendidikan umum? Apakah pelajaran akan didasarkan atas disiplin ilmu ataukah dipusatkan pada masalah sosial dan pribadi? Apakah semua anak/ peserta didik harus mengikuti pelajaran yang sama ataukah diizinkan memilih pelajaran sesuai dengan minatnya?Apakah seluruh kurikulum sama bagi semua sekolah secara seragam ataukah diberi kelonggaran untuk menyesuaikannya dengan keadaan daerah? Apakah hasil belajar anak/peserta didik akan diuji secara seragam ataukah diserahkan pada penilaian guru yang dapat mempelajari anak/peserta didik itu dalam segala aspek selama kurun waktu yang panjang? Semua pertanyaan tersebut terkait erat dengan asas-asas yang menjadi landasan dalam pengembangan kurikulum. Setiap pengembangan kurikulum pada jenjang mana pun harus didasarkan pada asas-asas/landasan tertentu.

Selain itu, kebijakan pengembangan kurikulum juga merupakan salah satu faktor yang berpengaruh terhadap keberhasilan atau kegagalan implementasai dari pengembangan kurikulum tersebut. Kebijakan yang tepat akan berdampak positif terhadap efektivitas implementasi kurikulum, sebaliknya kebijakan yang tidak tepat akan berdampak negative terhadap efetivitas implementasi kurikulum.

\section{B. Pengertian Pengembangan Kurikulum}

Kata "kurikulum" berasal dari bahasa Yunani yang semula digunakan dalam bidang olahraga, yaitu currere yang berarti jarak tempuh lari, yakni yang harus ditempuh dalam kegiatan berlari mulai dari start hingga finish. Pengertian ini kemudian diterapkan dalam bidang pendidikan. Dalam bahasa Arab, untuk istilah "kurikulum" digunakan kata manhaj, yaitu jalan yang terang, atau jalan terang yang dilalui oleh manusia pada bidang kehidupannya. ${ }^{2}$ Dalam konteks pendidikan, kurikulum berarti

${ }^{2}$ Muhaimin, Pengembangan Kurikulum Pendidikan Agama Islam di Sekolah, Madrasah, dan Perguruan Tinggi, (Jakarta: Rajawali Pers, 2009), hlm. 1; dan Ali Isma'il Muhammad, al-Manhaj fi al-Lughah al-'Arabiyah, (Kairo: Maktabah Wahbah, 1997), hlm. 90. 
jalan terang yang dilalui oleh pendidik/guru dengan peserta didik untuk mengembangkan pengetahuan, keterampilan, dan sikap serta nilai-nilai.

Kurikulum, dalam pengertiannya yang lama, dipandang sebagai sekumpulan mata pelajaran yang telah diprogramkan (syllabus) untuk dipelajari oleh siswa. ${ }^{3}$ Dalam pengertian ini, kurikulum bahasa Arab umumnya lebih menekankan pada aspek kognitif (pengetahuan) berupa sejumlah kaidah grammar atau tata bahasa Arab (nahwu. Sharaf, dan balaghah), sedangkan aspek lainnya yang tak kalah penting, seperti keterampilan berbahasa (menyimak, berbicara, membaca, dan menulis), kurang mendapat perhatian. Selain itu, antara satu mata pelajaran dengan mata pelajaran lainnya umumnya dipelajari secara terpisah (berdiri sendiri), tidak terkait secara terpadu antara yang satu dengan lainnya. Ditambah lagi, tugas guru hanya terbatas menyampaikan pengetahuan tentang bahasa Arab dan cenderung lebih mendominasi proses belajar mengajar bahasa Arab. Semantara siswa bersikap pasif menerima apa yang disampaikan oleh guru.

Dewasa ini, pengertian kurikulum pendidikan bahasa Arab telah mengalami perkembangan. Kurikulum tidak lagi dianggap sekedar sejumlah mata pelajaran yang harus dipelajari oleh siswa, lebih dari itu, kurikulum juga mencakup pengalaman belajar, sebagaimana dikemukakan oleh Marsh \& Willis (1999): "curriculum is an interrelated set of plans and experience that a student undertakes under the guidance of the school". ${ }^{4}$ (Kurikulum adalah seperangkat rencana dan pengalaman belajar yang laksanakan oleh siswa di bawah bimbingan sekolah). Hal ini senada dengan pengertian kurikulum pendidikan bahasa Arab yang dikemukakan Thu'aimah (1989) sebagai berikut: ${ }^{5}$

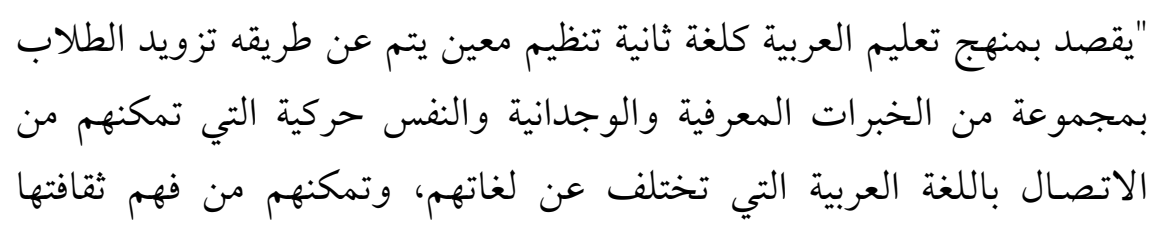

${ }^{3}$ Rusydi Ahmad Thu'aimah, Ta'lim al-Lughah al-'Arabiyah li ghayiri al-Nathiqiina biha: Manaahijuhu wa Asaaliibuhu, (Rabath: ISISCO, 1989), hlm. 59.

${ }^{4}$ Colin J. Marsh \& George Willis, Curriculum: Alternative Approaches, ongoing Issues, (New Jersey: Prentice-Hall, Inc., 1999), hlm. 11.

${ }^{5}$ Rusydi Ahmad Thu'aimah, Op. Cit., hlm. 60. 


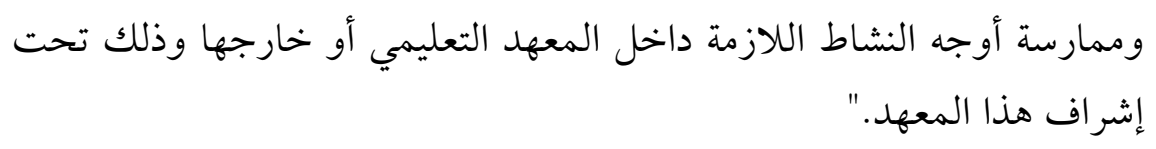

Pengertian tersebut lebih menekankan kurikulum bahasa Arab sebagai program pembelajaran yang terencana secara sistematis dengan memberikan kepada para siswa berbagai pengalaman belajar bahasa Arab, yang mencakup aspek kognitif (pengetahuan), afektif (sikap), dan psikomor (keterampilan), baik di dalam lingkungan sekolah ataupun di luar sekolah namun tetap dalam bimbingan dan tanggung jawab sekolah, dengan tujuan agar mereka mampu berkomunikasi dengan bahasa Arab serta memahami kebudayaan Arab.

Selanjutnya, menurut Muhaimin (2009), ${ }^{6}$ selain pengertian kurikulum yang menekankan isi dan yang menekankan proses serta pengalaman tersebut, terdapat pengertian ketiga, yang berusaha memadukan keduaduanya, dalam arti ia menekankan baik pada isi maupun proses pendidikan atau pengalaman belajar sekaligus. Isi pendidikan terdiri dari problemproblem aktual yang dihadapi dalam kehidupan nyata di masyarakat. Proses pendidikan atau pengalaman belajar peserta didik berbentuk kegiatan belajar kelompok yang mengutamakan kerja sama, baik antar peserta didik, peserta didik dengan guru/dosen, maupun antar peserta didik dan guru/dosen dengan sumber-sumber belajar yang lain.

Oleh karena itu, dalam menyusun kurikulum atau program pendidikan bertolak dari problem yang dihadapi dalam masyarakat sebagai isi pendidikan, sedangkan proses atau pengalaman belajar peserta didik adalah dengan cara memerankan ilmu-ilmu dan teknologi, serta bekerja secara kooperatif dan kolaboratif, berupaya mencari pemecahan terhadap problem tersebut menuju pembentukan masyarakat yang lebih baik. Adapun kegiatan penilaian dilakukan untuk hasil maupun proses belajar. Guru/dosen melakukan kegiatan penilaian sepanjang kegiatan belajar.

Nampaknya, pengertian kurikulum yang memadukan antara isi dan proses serta pengalaman belajar inilah yang dikehendaki oleh UU Sisdiknas Nomor 20 Tahun 2003 Pasal 1 ayat 19 bahwa kurikulum adalah seperangkat rencana dan pengaturan mengenai tujuan, isi, dan bahan pelajaran serta cara yang digunakan sebagai pedoman penyelenggaraan kegiatan pembelajaran untuk mencapai tujuan pendidikan tertentu.

\footnotetext{
${ }^{6}$ Muhaimin, Op. Cit., hlm. 5.
} 
Selanjutnya, kurikulum bukanlah suatu program pembelajaran yang bersifat statis, melainkan harus selalu dinamis, artinya dapat mengalami pengembangan, bahkan perubahan sesuai dengan tuntutan dan kebutuhan dunia pendidikan. Meskipun demikian, pengembangan kurikulum tidak dapat dilakukan secara sembarangan dan asal jadi. Pengembangan kurikulum membutuhkan landasan yang kuat, yang didasarkan pada berbagai hasil pemikiran dan penelitian yang mendalam. Pengembangan kurikulum yang tidak didasarkan pada landasan yang kuat dapat berakibat fatal terhadap kegagalan pendidikan itu sendiri.

\section{Landasan Pengembangan Kurikulum Bahasa Arab}

Landasan adalah sesuatu yang di atasnya berdiri sesuatu dengan kukuh. Dalam sebuah bangunan, landasan sama artinya dengan fondasi yang di atasnya bangunan tersebut ditegakkan. Fungsi landasan pengembangan kurikulum adalah seperti fondasi sebuah bangunan. Untuk membangun sebuah gedung yang kukuh dan tahan lama, diperlukan fodasi yang kukuh pula. Semakin kukuh fondasi sebuah gedung, maka akan semakin kukuh pula gedung tersebut. Demikian pula halnya dengan pengembangan kurikulum, harus berlandaskan pada fondasi yang kuat.

\section{Landasan Religius}

Al-Qur'an diturunkan oleh Allah SWT dengan bahasa Arab, ${ }^{7}$ demikian pula hadits-hadits Rasulullah SAW disampaikan dalam bahasa Arab. Jadi, bahasa Arab merupakan alat komunikasi yang digunakan untuk menyampaikan ajaran agama Islam. Dengan demikian, untuk dapat memahami sumber ajaran agama Islam (al-Qur'an dan al-Hadits) dan berbagai macam ilmu pengetahuan keislaman dengan benar diperlukan penguasaan bahasa Arab yang memadai.

Lebih dari itu, bacaan-bacaan shalat, dzikir, do'a, dan adzan pun yang sudah rutin dilakukan umat Islam di seluruh dunia, menggunakan bahasa Arab. Untuk dapat mengucapkan bacaan tersebut dengan fasih serta memahami maknanya, perlu mempelajari bahasa Arab. Sehingga dapat dikatakan bahwa bagi umat Islam, di samping sebagai alat komunikasi dunia (internasional), bahasa Arab merupakan bahasa Agama. Dalam hal ini, Ali Isma'il Muhammad (1997) menegaskan bahwa hubungan antara

${ }^{7}$ Q.S. Fushilat, Ayat: 3; Q.S. Az-Zumar, Ayat: 28. 
bahasa Arab dan ilmu-ilmu keislaman bagaikan satu kesatuan anggota tubuh, satu sama lain tak dapat dipisahkan. ${ }^{8}$

Dengan demikian, bagi umat Islam, tujuan pendidikan bahasa Arab tak dapat dilepaskan dari tujuan memahami sumber ajaran Islam beserta berbagai ilmu pengetahuannya. Penguasaan bahasa Arab sangat penting dalam membantu memahami sumber ajaran Islam (al-Qur'an dan alHadits) serta berbagai literatur keislaman berbahasa Arab yang merupakan khazanah kekayaan intelektual dan peradaban Islam. Oleh karena itu, pengembangan kurikulum bahasa Arab perlu mempertimbangkan landasan religius tersebut.

\section{Landasan Filosofis}

Bahasa merupakan merupakan sesuatu yang inherent dalam diri manusia sebagai karunia Allah SWT untuk manusia. Bahkan Allah SWT sendiri menampakkan diri pada manusia bukan melalui zat-Nya, tetapi melalui bahasa-Nya, yaitu bahasa alam (ayat kauniyah) dan kitab suci (ayat qauliyah), ${ }^{9}$ dengan menggunakan bahasa Arab. Oleh karena itu, upaya mempelajari bahasa Arab merupakan suatu kewajiban dan sekaligus merupakan amal shaleh.

Selanjutnya, salah satu aliran filsafat yang sangat berpengaruh dalam dunia pendidikan dewasa ini adalah filsafat konstruktivisme. Konstruktivisme berpandangan bahwa pengetahuan adalah konstruksi manusia melalui interaksi dengan objek, fenomena, pengalaman, dan lingkungannya. Suatu pengetahuan dianggap benar bila pengetahuan itu dapat berguna untuk menghadapi dan memecahkan persoalan atau fenomena yang sesuai. Dalam pandangan konstruktivisme, pengetahuan tidak dapat ditransfer begitu saja dari seseorang (guru/dosen) kepada orang lain (siswa/mahasiswa), tetapi harus diinterpretasikan sendiri oleh masingmasing orang. Setiap orang harus mengkonstruksi pengetahuan sendiri. Pengetahuan bukan sesuatu yang sudah jadi, melainkan suatu proses yang berkembang terus-menerus. Dalam prose situ, keaktifan seseorang yang ingin tahu amat berperan dalam perkembangan pengetahuannya. ${ }^{10}$

\footnotetext{
${ }^{8}$ Ali Isma'il Muhammad, Op. Cit., hlm. 24.

9 Asep Ahmad Hidayat, Filsafat Bahasa: Mengungkap Hakikat Bahasa, Makna, dan Tanda, (Bandung: Remaja Rosdakarya, 2009), hlm. 21.

10 Paul Suparno, Filsafat Konstruktivisme dalam Pendidikan, (Yogyakarta: Kanisius, 1997), hlm. 28.
} 
Berdasarkan pandangan konstruktivisme tersebut, kurikulum pembelajaran bahasa Arab perlu dikembangkan dalam model pembelajaran yang mampu melibatkan peserta didik secara aktif membangun pengetahuan dan keterampilan bahasa Arab yang mencakup keterampilan menyimak, berbicara, membaca dan menulis. Agar peserta didik terlibat aktif dalam proses pembelajaran bahasa Arab, perlu dikembangkan model kurikulum pembelajaran bahasa Arab yang berpusat pada siswa (student centered curriculum).

\section{Landasan Yuridis}

Landasan yuridis untuk pengembangan dan penyusunan kurikulum bahasa Arab pada tingkat satuan pendidikan dasar dan menengah serta pendidikan tinggi mengacu pada:

1. Undang Undang Nomor 20/2003 tentang Sistem Pendidikan Nasional Pasal 36, 37, dan 38;

2. Peraturan Pemerintah Nomor 19 Tahun 2005 tentang Standar Nasional Pendidikan;

3. Peraturan Menteri Agama Nomor 2 Tahun 2008 tentang Standar Isi (SI) dan Standar Kompetensi Lulusan (SKL) untuk satuan pendidikan dasar dan menengah di madrasah (MI, MTs, dan MA).

Di dalam UU Nomor 20 Tahun 2003 Tentang Sisdiknas Pasal 36 Ayat (1) dan (2) juga dalam PP Nomor 19 Tahun 2005 Pasal 17 ayat (1) diberikan otonomi kepada satuan pendidikan dasar dan menengah untuk mengembangkan kurikulum (termasuk kurikulum bahasa Arab) sesuai dengan satuan pendidikan, potensi daerah/karakteristik daerah, sosial budaya masyarakat setempat, dan peserta didik. Namun demikian, pengembangan kurikulum itu harus tetap mengacu pada standar nasional pendidikan.

Selanjutnya, dalam Peraturan Menteri Agama Nomor 2 Tahun 2008 tentang Standar Isi dan Standar Kompetensi Lulusan Mata Pelajaran Pendidikan Agama Islam dan Bahasa Arab di Madrasah dijelaskan bahwa Standar Kompetensi Lulusan mata pelajaran bahasa Arab MI, MTs, dan MA mencakup empat keterampilan bahasa Arab: menyimak, berbicara, membaca, dan menulis. 


\section{Landasan Linguistik}

Perbedaan dalam cara atau mengajarkan bahasa dipengaruhi pula oleh perbedaan pandangan terhadap hakekat bahasa dan perbedaan dalam cara menganalisis dan mendeskripsikan bahasa. Pada bagian ini akan dikemukakan dua aliran paling penting saat ini dalam ilmu bahasa (linguistic), yaitu aliran strukturalisme dan aliran transformasi- generatif. ${ }^{11}$

a) Aliran Strukturalisme

Aliran ini dipelopori oleh linguis dari Swiss, Ferdinand de Saussure (1857-1913) dan dikembangkan lebih lanjut oleh Leonard Bloomfield. Aliran strukturalisme ini memiliki pandangan tentang hakekat bahasa, antara lain:

1. Bahasa itu adalah ujaran (lisan)

2. Kemampuan bahasa diperoleh melalui kebiasaan yang ditunjang dengan latihan dan penguatan

3. Setiap bahasa memilki sistemnya sendiri yang berbeda dari bahasa lain. Oleh karena itu, menganalisis suatu bahasa tidak bisa memakai kerangka yang digunakan untuk menganalisis bahasa lainnya

4. Setiap bahasa memiliki system yang utuh dan cukup untuk mengekspresikan maksud dari penuturnya. Oleh karena itu, tidak ada suatu bahasa yang unggul atas bahasa lainnya.

5. Semua bahasa yang hidup berkembang mengikuti perubahan zaman terutama karena terjadinya kontak dengan bahasa lain. Oleh karena itu, kaidah-kaidahnya pun bisa mengalami perubahan.

6. Sumber pertama dan utama kebakuan bahasa adalah penutur bahasa tersebut, bukan lembaga ilmiah, pusat bahasa, atau mazhab-mazhab gramatika.

Berdasarkan teori-teori bahasa tersebut, ditetapkan beberapa prinsip mengenai pembelajaran bahasa, antara lain:

1. Karena kemampuan berbahasa diperoleh melalui kebiasaan, maka latihan menghafalkan dan menirukan berulang-ulang harus diintensifkan. Guru harus mengambil peran utama dalam proses pembelajaran bahasa.

${ }^{11}$ Ahmad Fuad Effendy, Metodologi Pengajaran Bahasa Arab, (Malang: Misykat, 2009), hlm. 17-21. 
2. Karena bahasa lisan merupakan sumber utama bahasa, maka guru harus memulai pelajaran dengan menyimak kemudian berbicara, sedangkan membaca dan menulis dilatihkan kemudian.

3. Hasil analisis kontrastif (perbandingan antara bahasa ibu dan bahasa yang dipelajari) dijadikan dasar pemilihan materi pelajaran dan latihan-latihan.

4. Diberikan perhatian yang besar kepada wujud luar dari bahasa, yaitu pengucapan yang fasih, ejaan dan pelafalan yang akurat, struktur yang benar, dan sebagainya.

Teori-teori linguistic structural ini seiring dengan teori-teori psikologi behaviorisme dan menjadi landasan teoritis bagi metode audiolingual dalam pembelajaran bahasa.

b) Aliran Generatif-Transformatif

Aliran Generatif-Transformatif ini dipelopori oleh seorang pakar linguistic Amerika yang bernama Noam Chomsky. Dia membagi kemampuan kemampuan berbahasa menjadi dua, yaitu kompetensi dan performansi. Kompetensi (competence) adalah kemampuan ideal yang dimiliki oleh seorang penutur bahasa. Kompetensi menggambarkan pengetahuan tentang system bahasa yang sempurna, yaitu pengetahuan tentang system kalimat (sintaks), system kata (morfologi), system bunyi (fonologi), dan system makna (semantic). Sedangkan performansi (performance) adalah ujaran-ujaran yang bisa didengar atau dibaca, yang merupakan tuturan seseorang apa adanya tanpa dibuat-buat. Oleh karena itu, performansi bisa saja tidak sempurna, dan oleh karena itu pula, menurut Chomsky, suatu tata bahasa hendaknya memerikan kompetensi dan bukan performansi.

Dalam beberapa hal, teori kebahasaan dalam aliran geberatiftransformatif ini memiliki kesamaan dengan aliran structural. Pertama, Pada dasarnya bahasa itu adalah ujaran (lisan). Kedua, bahasa memiliki system yang utuh dan cukup memadai untuk mengekspresikan maksud dari penuturnya, oleh karena itu, tidak ada suatu bahasa yang lebih unggul atas bahasa lainnya. Namun demikian, terdapat beberapa perbedaan di antara keduanya, antara lain:

1. Menurut aliran structural, kemampuan berbahasa diperoleh melalui kebiasaan yang ditunjang dengan latihan dan penguatan. 
Sedangkan aliran transformatif-generatif menekankan bahwa kemampuan berbahasa adalah sebuah proses kreatif.

2. Aliran structural menekankan adanya perbedaan system antara satu bahasa dengan bahasa lainnya, sementara aliran transformatifgeneratif menegaskan adanya banyak unsur kesamaan di antara bahasa-bahasa, terutama pada tataran struktur dalamnya.

3. Aliran structural berpandangan bahwa semua bahasa yang hidup berkembang mengikuti perubahan zaman, terutama karena terjadinya kontak dengan bahasa lain, oleh karena itu, kaidahkaidah bahasa pun bisa mengalami perubahan. Sedangkan aliran transformatif-generatif menyatakan bahwa perubahan itu hanya menyangkut struktur luar, sedangkan struktur dalamnya tidak berubah sepanjang masa dan tetap menjadi dasar bagi setiap perkembangan yang terjadi.

Berdasarkan teori-teori kebahasaan tersebut, dirumuskan prinsipprinsip mengenai pembelajaran bahasa, antara lain:

1. Karena kemampuan berbahasa adalah sebuah proses kreatif, maka pembelajar harus diberi kesempatan yang luas untuk mengkreasi ujaran-ujaran dalam situasi komunkatif yang sebenarnya, bukan sekedar menirukan dan menghafalkan.

2. Pemilihan materi pelajaran tidak ditekankan pada hasil analisis kontrastif, melainkan pada kebutuhan komunikasi dan penguasaan fungsi-fungsi bahasa.

3. Kaidah grammar/nahwu dapat diberikan sepanjang hal itu diperlukan oleh pembelajar sebagai landasan untuk dapat mengkreasi ujaran-ujaran sesuai dengan kebutuhan komunikasi.

\section{Landasan Psikolinguistik}

Para pakar psikologi pembelajaran sepakat bahwa dalam proses belajar-mengajar terdapat unsur-unsur (1) internal, yaitu bakat, minat, kemauan dan pengalaman terdahulu dalam diri pembelajar; dan (2) eksternal, yaitu lingkungan, guru, buku teks, dsb. Permasalahannya adalah unsur manakah yang merupakan factor dominan atau paling besar pengaruhnya dalam proses pembelajaran? Jawaban atas pertanyaan ini dapat ditelusuri melalui dua mazhab besar dalam psikologi, yaitu mazhab 
behaviorisme (al-sulukiyah) dan mazhab cognitive (al-ma' rifiyah). ${ }^{12}$ Mazhab pertama memberikan perhatian lebih besar kepada factor-faktor eksternal, sedangkan mazhab kedua lebih memfokuskan perhatiannya kepada factor internal.

\section{a. Mazhab Behaviorisme}

Mazhab behaviorisme menjelaskan pengertian tingkah laku melalui aksi dan reaksi atau stimulus menghasilkan response; stimulus yang berbeda menghasilkan responsi yang berbeda pula. Hubungan antara stimulus tertentu dengan responsi tertentu disebut kebiasaan atau habit. Yang menjadi masalah pokok adalah "bagaimana terjadinya hubungan antara stimulus dan responsi (S-R)?" Menurut aliran psikologi behaviorisme klasik, yang dipelopori oleh Watson, stimulus mendatangkan responsi. Apabila stimulus terjadi secara tetap maka responsi pun terlatih dan diarahkan tetap sehingga akhirnya bersifat otomatis. Aliran psikologi behaviorisme modern, dengan tokoh Skinner, berpendapat bahwa kebiasaan dapat terjadi dengan cara peniruan dan penguatan.

Walaupun teori pembentukan kebiasaan (habit formation) itu bersifat umum, aplikasinya digunakan juga dalam pengajaran bahasa. Di dalam pembelajaran bahasa pertama (B1), anak-anak menguasai bahasa ibunya melalui peniruan. Peniruan itu biasanya diikuti oleh pujian atau perbaikan. Melalui kegiatan itulah anak-anak mengembangkan pengetahuannya mengenai struktur, pola kebiasaan bahasa ibunya. Hal yang sama berlaku juga dalam pembelajaran bahasa kedua (B2) atau bahasa asing. Melalui cara peniruan dan penguatan, para siswa mengidentifikasi hubungan antara stimulus dan responsi yang merupakan kebiasaan dalam berbahasa kedua atau bahasa asing.

Dalam pembelajaran bahasa, aliran/mazhab behaviorisme ini melahirkan pendekatan aural-oral (thariqah sam'iyah syafawiyah). Dalam pendekatan ini, peran guru sangat dominant karena dialah yang memilih bentuk stimulus, memberikan ganjaran dan hukuman, memberikan penguatan dan menentukan jenisnya, dan dia pulalah yang memilih buku, materi, dan cara mengajarkannya, bahkan menentukan bentuk jawaban atas pertanyaan yang diajukan kepada pembelajar. Pendekatan ini memberikan perhatian utama kepada kegiatan latihan, drill, menghafal

${ }^{12}$ Ahmad Fuad Effendy, Ibid., hlm. 12-16 
kosa kata, dialog, teks bacaan, dan pada sisi lain lebih mengutamakan bentuk luar bahasa (pola, struktur, kaidah) dari pada kandungan isinya, dan mengutamakan kesahihan dan akurasi dari pada kemampuan interaksi dan komunikasi.

\section{b. Mazhab Kognitivisme}

Bertolak belakang dengan mazhab behaviorisme yang menekankan pentingnya stimulus eksternal dalam pembelajaran, mazhab cognitive menegaskan pentingnya keaktifan pembelajar. Pembelajarlah yang mengatur dan menentukan proses pembelajaran. Lingkungan bukanlah penentu awal dan akhir positif atau negatifnya hasil pembelajaran. Menurut pandangan mazhab ini, seseorang ketika menerima stimulus dari lingkungannya, dia melakukan pemilihan sesuai dengan minat dan keperluannya, menginterpretasikannya, menghubungkannya dengan pengalamannya terdahulu, baru kemudian memilih alternatif respon yang paling sesuai.

Para ahli psikolinguistik pengikut mazhab kognitive, antara lain Noam Chomsky dan James Deez, berpandangan bahwa setiap manusia memiliki kesiapan alamiah untuk belajar bahasa. Manusia lahir dibekali oleh Sang Pencipta dengan piranti pemerolehan bahasa atau LAD (Language Acquisition Device). Alat ini menyerupai layar radar yang hanya menangkap gelombang-gelombang bahasa. Setelah diterima, gelombang-gelombang itu ditata dan dihubung-hubungkan satu sama lain menjadi sebuah system kemudian dikirimkan ke pusat pengolahan kemampuan berbahasa (Language Competence). Pusat ini merumuskan kaidah-kaidah bahasa dari data-data ujaran yang dikirimkan oleh LAD dan menghubungkannya dengan makna yang dikandungnya, sehingga terbentuklah kemampuan berbahasa.

Pada tahap selanjutnya, pembelajar bahasa menggunakan kemampuan berbahasanya untuk mengkreasi atau menghasilkan kalimat-kalimat dalam bahasa yang dipelajarinya untuk mengungkapkan keinginan atau keperluannya sesuai dengan kaidah-kaidah yang telah diketahuinya.

\section{Landasan Sosiolinguistik}

Basyar (1997) dan Hudson (2002) menyatakan bahwa bahasa tidak bisa dipisahkan dari konteks sosial dan budaya. Bahasa merupakan bagian 
dari budaya dan fungsi sosial dari bahasa adalah sebagai alat komunikasi. ${ }^{13}$ Terdapat tujuh fungsi komunikatif bahasa, sebagai berikut: ${ }^{14}$

a. Instrumental function, yaitu menggunakan bahasa untuk memperoleh sesuatu yang diinginkan;

b. Regulatory function, yaitu menggunakan bahasa untuk mengarahkan atau memerintah orang lain;

c. Interactional function, yaitu menggunakan bahasa untuk saling mengungkapkan pikiran dan perasaan satu sama lain;

d. Personal function, yaitu menggunakan bahasa untuk mengungkapkan pikiran dan perasaan pribadi;

e. Heuristic function, yaitu menggunakan bahasa untuk meminta penjelasan atau mengungkapkan rasa ingin tahu;

f. Imaginative function, yaitu menggunakan bahasa untuk mengungkapkan daya imajinasi seseorang walaupun tidak sesuai dengan kenyataan; dan

g. Representational function, yaitu menggunakan bahasa untuk menyampaikan informasi kepada orang lain;

Oleh karena itu, pembelajaran bahasa Arab hendaknya diorientasikan pada penguasaan kompetensi komunikatif, artinya pembelajaran bahasa Arab tidak sekedar bertujuan pada penguasaan tentang kaidah tata bahasa saja (nahwu-sharaf), namun juga mampu menggunakan bahasa Arab sebagai alat komunikasi. Dalam hal ini, ada empat macam kompetensi komunikatif yang perlu dipertimbangkan dalam pengembangan kurikulum bahasa Arab, sebagai berikut: ${ }^{15}$

a. Gramatical competence, yaitu memiliki pengetahuan tentang sistem bahasa Arab (bunyi, kosa kata, dan nahwu-sharaf) dan mampu menggunakannya;

${ }^{13}$ Kamal Basyar, 'Ilmu al-Lughah al-Ijtima'iy, (al-Qahirah: Dar Gharib, 1997), hlm. 239; Lihat juga Hudson, 'Ilmu al-Lughah al-Ijtima'iy, terj. Mahmud 'Iyad, (al-Qahirah: 'Alam al-Kutub, 2002), hlm. 16.

${ }^{14}$ Rusydi Ahmad Thu'aimah dan Mahmud Kamil al-Naqah, Ta'liim al-Lughah Ittishaaliyan: Baina al-Manahij wa al-Istraatijiyaat, (Rabath: ISISCO, 2006), hlm. 28-29.

${ }^{15}$ Ibid., hlm. 50-51; Lihat juga Sandra J. Savignon, Communicative Competence: Theory and Classroom Practice, (Massachusetts: Addison-Wesley Publishing Company, Inc., 1983), hlm. 36-40. 
b. Sociolinguistic competence, yaitu kemampuan memahami konteks sosial di mana komunikasi berlangsung dan mampu berinteraksi dengan masyarakat penutur bahasa yang dipelajari.

c. Discourse competence, yaitu kemampuan menafsirkan hubungan-hubungan kalimat atau ujaran untuk mengkonstruk makna yang utuh;

d. Strategic competence, yaitu kemampuan menggunakan strategi komunikasi untuk memulai komunikasi, mempertahankan jalannya komunikasi, dan mengakhiri/menutup komunikasi.

\section{Landasan Ilmu Pengetahuan dan Teknologi}

Perkembangan yang demikian cepat dalam bidang ilmu pengetahuan dan teknologi telah mampu merubah tatanan kehidupan manusia. Oleh karena itu, kurikulum seyogyanya dapat mengakomodir dan mengantisipasi laju perkembangan ilmu pengetahuan dan teknologi, sehingga peserta didik dapat mengimbangi dan sekaligus mengembangkan ilmu pengetahuan dan teknologi untuk kemaslahatan dan kelangsungan hidup manusia.

Pengembangan kurikulum bahasa Arab juga harus mampu mengikuti perkembangan ilmu pengetahuan dan teknologi, sekaligus memanfaatkan sisi positif dari kemajuan ilmu pengetahuan tersebut untuk pengembangan program pembelajaran bahasa Arab. Misalnya, merancang program pembelajaran bahasa Arab dengan diperlengkapi media audiovisual dalam bentuk kaset rekaman atau $C D$, mengembangkan program pembelajaran bahasa Arab model e-learning, memanfaatkan internet untuk pembelajaran bahasa Arab, dan sebagainya.

Berbagai hasil penelitian menunjukkan bahwa pemanfaatan kemajuan teknologi dapat meningkatkan efektivitas pembelajaran bahasa Arab. Hasil penelitian Nasruddin (2011) menunjukkan bahwa penggunaan film pembelajaran dapat meningkatkan keterampilan menyimak bahasa 
Arab. ${ }^{16}$ Selanjutnya, hasil penelitian Inayah ${ }^{17}$ (2011) dan Ma'arif ${ }^{18}$ (2011) juga menunjukkan bahwa pengembangan bahan ajar bahasa Arab dengan menggunakan multimedia berupa $\mathrm{CD}$ interaktif dapat meningkatkan keterampilan berbicara dan membaca bahasa Arab. Selain itu, motivasi siswa dalam belajar bahasa Arab juga meningkat.

\section{Simpulan}

Kurikulum dan pembelajaran merupakan dua hal yang tidak dapat dipisahkan. Kurikulum berfungsi sebagai pedoman yang memberikan arah dan tujuan pendidikan serta isi yang harus dipelajari, sedangkan pembelajaran adalah proses yang terjadi dalam interaksi belajar dan mengajar antara guru dan siswa. Tanpa kurikulum yang jelas sebagai acuan, maka pembelajaran tidak akan berlangsung secara efektif. Demikian pula, kurikulum tidak akan bermakna jika tidak diimplementasikan dalam proses pembelajaran.

Pengembangan kurikulum bahasa Arab adalah proses yang tak pernah berhenti yang harus dilakukan secara kontinu. Jika tidak, maka kurikulum tersebut menjadi usang atau ketinggalan zaman. Namun demikian, pengembangan kurikulum tidak bisa dilakukan dengan asal jadi atau secara sembarangan. Untuk menghasilkan kurikulum bahasa Arab yang berkualitas harus berpijak pada landasan yang kukuh, antara lain: landasan religius, filosofis, yuridis, linguistik, psikololinguistik, sosiolinguitik, dan landasan ilmu pengetahuan dan teknologi

\section{DAFTAR PUSTAKA}

Basyar, Kamal, 1997, 'Ilmu al-Lughah al-Ijtima'iy, al-Qahirah: Dar Gharib.

16 Nasruddin, 2011, Fa'aliyah Istikhdaam al-Aflaam al-Ta'limiyah Li Tanmiyah Maharah al-Istima' (Studi Eksperimen di MTs Ulumul Qur'an Langsa Aceh), Tesis. Program Pasca Sarjana UIN Maulana Malik Ibrahim Malang. Tidak diterbitkan.

17 Inayah, 2011, Tathwir al-Mawad al-Ta'limiyah Bil Hasuub Li Tarqiyati Maharah alKalam (Penelitian Pengembangan pada MA Radhatul Ulum Guyangan Trangkil Jawa Tengah), Tesis. Program Pasca Sarjana UIN Maulana Malik Ibrahim Malang. Tidak diterbitkan.

18 Ahmad Syamsul Ma'arif, 2011, Tathwir al-Mawad al-Talimiyah Bil Hasuub Li Tarqiyati Maharah al-Qira'ah (Penelitian Pengembangan pada MA Bilingual Batu Jawa Timur), Tesis. Program Pasca Sarjana UIN Maulana Malik Ibrahim Malang. Tidak diterbitkan. 
Effendy, Ahmad Fuad, 2009, Metodologi Pengajaran Bahasa Arab, Malang: Misykat.

Hidayat, Asep Ahmad, 2009, Filsafat Bahasa: Mengungkap Hakikat Bahasa, Makna, dan Tanda, Bandung: Remaja Rosdakarya.

Hudson, 'Ilmu al-Lughah al-Ijtima'iy, 2002, terj. Mahmud 'Iyad, al-Qahirah: 'Alam al-Kutub.

Inayah, 2011, Tathwir al-Mawad al-Ta'limiyah Bil Hasuub Li Tarqiyati Maharah al-Kalam (Penelitian Pengembangan pada MA Radhatul Ulum Guyangan Trangkil Jawa Tengah), Tesis. Program Pasca Sarjana UIN Maulana Malik Ibrahim Malang. Tidak diterbitkan.

Ahmad Syamsul Ma'arif, 2011, Tathwir al-Mawad al-Talimiyah Bil Hasuub Li Tarqiyati Maharah al-Qira'ah (Penelitian Pengembangan pada MA Bilingual Batu Jawa Timur), Tesis. Program Pasca Sarjana UIN Maulana Malik Ibrahim Malang. Tidak diterbitkan.

Marsh, Colin J. \& George Willis, 1999, Curriculum: Alternative Approaches, ongoing Issues, New Jersey: Prentice-Hall, Inc.

Muhaimin, 2009, Pengembangan Kurikulum Pendidikan Agama Islam di Sekolah, Madrasah, dan Perguruan Tinggi, Jakarta: Rajawali Pers.

Muhaimin dkk., 2009, Pengembangan Model Kurikulum Tingkat Satuan Pendidikan (KTSP) pada Sekolah dan Madrasah, Jakarta: Rajawali Pers.

Muhammad, Ali Isma'il, 1997, al-Manhaj fi al-Lughah al-'Arabiyah, Kairo: Maktabah Wahbah.

Nasruddin, 2011, Fa'aliyah Istikhdaam al-Aflaam al-Ta'limiyah Li Tanmiyah Maharah al-Istima' (Studi Eksperimen di MTs Ulumul Qur'an Langsa Aceh), Tesis. Program Pasca Sarjana UIN Maulana Malik Ibrahim Malang. Tidak diterbitkan.

Nasution, S., Asas-Asas Kurikulum, Jakarta: Bumi Aksara, 2006.

Rohman, Arif dan Teguh Wiyono, 2010, Education Policy in Decentralization Era, Yogyakarta: Pustaka Pelajar.

Suparno, Paul, 1997, Filsafat Konstruktivisme dalam Pendidikan, Yogyakarta: Kanisius.

Peraturan Pemerintah Nomor 19 Tahun 2005 tentang Standar Nasional Pendidikan. 
Peraturan Menteri Agama Nomor 2 Tahun 2008 tentang Standar Isi (SI) dan Standar Kompetensi Lulusan (SKL) untuk satuan pendidikan dasar dan menengah di madrasah.

Savignon, Sandra J., 1983, Communicative Competence: Theory and Classroom Practice, Massachusetts: Addison-Wesley Publishing Company, Inc.

Thu'aimah, Rusydi Ahmad, 1989, Ta'lim al-'Arabiyah li Ghayiri al-Nâthiqiîna biha: Manaâhijuhu wa Asaâliîbuhu, Rabath: ISISCO.

Thu'aimah, Rusydi Ahmad dan Mahmud Kamil al-Naqah, 2006, Ta'liim al-Lughah Ittishaaliyan: Baina al-Manahij wa al-Istraatijiyaat, Rabath: ISISCO.

Tilaar, H.A.R. dan Riant Nugroho, 2009, Kebijakan Pendidikan: Pengantar untuk Memahami Kebijakan Pendidikan dan Kebijakan Pendidikan Sebagai Kebijakan Publik, Yogyakarta: Pustaka Pelajar.

Undang-Undang Nomor 20 Tahun 2003 tentang Sistem Pendidikan Nasional. 